\title{
Influence of Dry Rum Distillery Slops in Diets for White Leghorn Hens on Laying Rate, Feed Conversion, and Egg Size and Quality ${ }^{1,2}$
}

\author{
Manuel Soldevila and Renato Irizarry 3
}

\begin{abstract}
Balanced (isonitrogenous and isocaloric) diets containing from 0 to $35 \%$ dried cane molasses rum distillery slops were compared using individually caged White Leghorn hens of the Kimber strain.

When production and feed utilization were compared, a stepwise decrease, more pronounced with levels above $20 \%$, was evident with increases in the slops content of the diets. Eggs were permanently stained and hens markedly soiled when consuming diets with levels of dry slops higher than $15 \%$.

Averages of egg weight, hen weight, broken-open egg height (inner quality), and shell thickness were not affected by levels of dry slops as high as $35 \%$ in the diets.

The high levels of $\mathrm{K}, \mathrm{Mg}$, and $\mathrm{SO}_{4}$ present in the experimental diets did not affect the calcium metabolism involved in shell formation.
\end{abstract}

\section{INTRODUCTION}

Morell de González and Molini (5) have reported that approximately 300 million gal (1.1 billion l) equivalent to 400 million lb (180 million $\mathrm{kg}$, dry basis equivalent) of sugarcane slops are produced annually in the four rum distilleries operating in Puerto Rico. This residue is at present dumped crude into the nearby ocean waters, causing a contamination problem. Local and federal environmental control agencies are enforcing laws and regulations that will terminate the present contaminating method of disposal. The economically feasible utilization of this residue either as a feed ingredient $(2,3)$ for chickens, or a soil conditioner (8), are two of the possibilities being explored at present by the Station.

Díaz-Medina and Randel (3) found that levels of $20 \%$ or less of dried slops did not have a serious detrimental effect on egg production. They did not compensate for caloric dilution due to dried slops addition to the ration. The objective of the work reported herein was to determine the effect of dry slops in compensated isonitrogenous and isocaloricbalanced diets.

' Manuscript submitted to Editorial Board February 10, 1977.

${ }^{2}$ The dried rum distillery slops were prepared by the Rum Pilot Plant, Agricultural Experiment Station, Rio Piedras, following the method described by Saavedra and others (9).

${ }^{3}$ Animal Nutritionist, and Associate Agronomist, Lajas Substation, respectively, Agricultural Experiment Station, Mayagüez Campus, University of Puerto Rico, Río Piedras, P.R. 
MATERIALS AND METHODS

The composition of dry sugarcane slops ${ }^{4}$ is described in the following tabulation:

\begin{tabular}{lr}
\multicolumn{1}{c}{ Component } & \multicolumn{1}{c}{$\%$} \\
$\mathrm{H}_{2} \mathrm{O}$ & 10.00 \\
$\mathrm{~N}$ & 1.30 \\
$\mathrm{~K}$ & 6.00 \\
$\mathrm{Ca}$ & 1.70 \\
$\mathrm{P}$ & .03 \\
$\mathrm{Mg}$ & 1.70 \\
$\mathrm{Na}$ & .45 \\
$\mathrm{SO}_{4}$ & 3.00 \\
Sucrose & 40.00 \\
Reducing sugars & 6.00 \\
Caramel & 29.00 \\
Others & .82
\end{tabular}

The high content of $\mathrm{K}$ and $\mathrm{Mg}$ in such a residue (5) has moved the Rum Pilot Plant staff to develop a demineralization technique that will lower their content, and thus increase the potential nutritive value of the dried slops. Their efforts have been partially successful, but the technique is not commercially and economically feasible at the present time.

Eight levels of dry slops $(0,5,10,15,20,25,30$, and $35 \%)$ were evaluated in a study carried out with Leghorn hens of the Kimber strain, individually fed and housed in wire cages over water pits at the Lajas Substation. The experiment began in April 1976, when the pullet flock reached a 50\% laying intensity, and lasted for twelve weeks. Egg production, egg weight, efficiency of feed utilization, inner egg quality (broken open egg height), and shell thickness were used as criteria for comparison.

A partially balanced incomplete block design with three two-bird replicates (housed in adjacent wire cages) per treatment was used.

The basal diets used in this study are described below:

\section{Ingredient}

Corn (yellow), ground

Slops, dried

Soybean meal

Tuna fishmeal

Limestone, ground

Dicalcium phosphate

Tallow, stabilized
Nonslops constituents

$\%$

73.5

-
-

10.0

9.9

4.5

1.5 slops diet ${ }^{3}$ $\%$

32.2

35.0

9.5

9.9

2.5

1.5

Ingredient content of $35 \%$

8.3

"See reference 8 in Literature cited. Confirmed by I. Morell de González et al. (personal communication).

${ }^{5}$ To obtain the intermediate levels $(5,10,15,20,25$, and $30 \%)$, different proportions of the 0 and $35 \%$ diets were combined and homogenized. 
$\mathrm{NaCl}^{6}$

Premix ${ }^{\top}$

Crude protein, calculated

Calcium, calculated

Phosphorus, calculated

Productive energy, calculated

$(\mathrm{Cal} / \mathrm{Kg})^{\mathrm{r}}$

$\begin{array}{rr}.5 & 1.0 \\ .1 & .1 \\ 15.02 & 15.03 \\ 2.72 & 2.77 \\ .91 & .81 \\ 2180 & 2180\end{array}$

1.0

15.03

2.77

81

2180

Chemical analyses of all ingredients was conducted to insure formulating and preparing isonitrogenous and isocaloric balanced diets $(1,4$, $6,7,10)$.

\section{RESULTS AND DISCUSSION}

The results of the experiment are summarized in table 1 . When production was compared, levels as high as $20 \%$ dry slops were not

TABLE 1. - Average data for the different treatments (diets)'

\begin{tabular}{|c|c|c|c|c|c|c|c|c|c|c|}
\hline \multirow{2}{*}{$\begin{array}{l}\text { Dry } \\
\text { slops } \\
\%\end{array}$} & \multirow{2}{*}{$\begin{array}{c}\text { Laying ef- } \\
\text { ficiency } \\
\%\end{array}$} & \multicolumn{2}{|c|}{ Hen weight } & \multicolumn{2}{|c|}{$\begin{array}{l}\text { Feed } \\
\text { utilization } \\
\text { efficiency }\end{array}$} & \multicolumn{2}{|c|}{$\begin{array}{c}\text { Egg weight } \\
\% \text { of the } 56.75 \mathrm{~g} \\
\text { standard }\end{array}$} & \multicolumn{2}{|c|}{$\begin{array}{c}\text { Shell } \\
\text { thickness }\end{array}$} & \multirow{2}{*}{$\begin{array}{c}\begin{array}{c}\text { Broken } \\
\text { open } \\
\text { egg } \\
\text { height }\end{array} \\
M m\end{array}$} \\
\hline & & $K g$ & $(L b)$ & $\overline{K g} / \mathrm{eg} g$ & $(L b / d o z)$ & $\begin{array}{c}1 \text { st } \\
\text { month }\end{array}$ & $\begin{array}{c}\text { Complete } \\
\text { study }\end{array}$ & $C m$ & (in) & \\
\hline 0 & $70.3 \mathrm{a}$ & 1.82 & $(4.01)$ & $0.19 a$ & $(4.96)$ & 86.0 & 106.2 & 0.036 & 0.014 & 17.8 \\
\hline 5 & $63.8 \mathrm{a}$ & 1.80 & (3.95) & $.19 \mathrm{a}$ & $(5.03)$ & 86.4 & 107.4 & .038 & .015 & 18.1 \\
\hline 10 & $59.3 \mathrm{a}$ & 1.61 & (3.54) & $19 a$ & $(5.01)$ & 83.0 & 101.6 & .036 & .014 & 17.0 \\
\hline 15 & $62.1 \mathrm{a}$ & 1.77 & (3.89) & $.17 \mathrm{a}$ & $(4.60)$ & 83.8 & 98.2 & .038 & .015 & 17.5 \\
\hline 20 & $49.0 \mathrm{ab}$ & 1.72 & (3.79) & $.23 \mathrm{ab}$ & $(6.14)$ & 82.6 & 98.6 & .036 & .014 & 15.9 \\
\hline 25 & $34.3 \mathrm{~b}$ & 1.79 & (3.94) & $.34 \mathrm{c}$ & $(8.86)$ & 84.1 & 101.8 & .036 & .014 & 17.0 \\
\hline 30 & $36.0 \mathrm{~b}$ & 1.67 & $(3.67)$ & $.30 \mathrm{bc}$ & $(7.94)$ & 78.8 & 94.2 & .033 & .013 & 17.1 \\
\hline 35 & $39.0 \mathrm{~b}$ & 1.66 & $(3.65)$ & $.28 \mathrm{bc}$ & $(7.42)$ & 84.4 & 98.1 & .033 & .013 & 17.3 \\
\hline
\end{tabular}

Means followed by one or more letters in common do not differ significantly at $\mathrm{P}=$ .05 level.

${ }^{2}$ Adjusted to the standard $56.75 \mathrm{~g}$ egg.

statistically different from the $0 \%$ when compared by the $t$ test, which differentiates between two given treatments. The regression equation $Y=70.32-1.06 X$, where $Y$ represents production and $X$ the $\%$ dry slops in the diets, was highly significant $(\mathrm{P}=.01)$. This relation indicates

${ }^{6} \mathrm{NaCl}$ was used as $1 \%$ in the $35 \%$ slops diet to counteract any possible deficiency brought about by an imbalance caused by the excess of other elements present in the slops fraction.

${ }^{7}$ Each $45.5 \mathrm{~kg}$ of diet contains 0.49 vitamins $\mathrm{A} / \mathrm{D}_{3}(500,000 / 100,000$ I.U./g); $90 \mathrm{mg}$ riboflavin; $270 \mathrm{mg}$ niacin; $11 \mathrm{~g}$ manganese sulfate $(75 \%) ; 90 \mathrm{~g}$ oxytetracycline $(3 \mathrm{~g}$ oxytetracycline and $3 \mathrm{mg}$ vitamin $\mathrm{B}_{12} / \mathrm{kg}$ ).

"See references 6, 7, and 10 in Literature Cited. Tabulated caloric values for sugarcane molasses were used as valid equivalent for the slops residue ( $90 \%$ dry matter basis) once the values were adjusted on a $70 \%$ dry matter (molasses) basis by multiplying the molasses value by 1.29 . 
that as slops level increased, production was decreased almost proportionately over the wide range of levels of slops evaluated (0-35\%). Increasing the level of dry slops $10 \%$, decreased production $10.6 \%$.

Díaz and Randel (3) using diets uncompensated for caloric concentration as compared to isocaloric diets in our study, did not find serious detrimental effects on egg production up to the level of $20 \%$ dry slops, which is in line with our findings. Nevertheless, the lower adjusted egg production as compared to that reported by them (3), could be ascribed to the fact that young birds during their first 4 months of production were used in this study, while older hens were used by them. In levels higher than $15 \%$, efficiency of feed utilization, as well as production, decreased markedly in contrast to the stepwise decrease from the first levels reported by them (3). Averages of hen weight, egg weight, inner quality, and shell thickness were not affected by the levels of dry slops present in the diets.

The consistent data for shell thickness, unaffected by level of dry slops in the diets, indicate that the calcium metabolism in the shell formation was not affected by high levels of $\mathrm{K}, \mathrm{Mg}$, and sulfates in the diets. In diets containing $35 \%$ dry slops, their content is approximately $2.1 \%, 0.6 \%$, and $1.1 \%$, respectively. Levels as high as these have been reported as possibly toxic for growing birds (6).

Most of the eggs produced by hens consuming levels of dry slops above $15 \%$ were stained, and once dry, the stain was not easily removed by washing. Caged animals became progressively more soiled as the level of dry-slop increased in the diet. If the hens were housed in floor pens, the eggs would probably not be stained. However, in the latter case, the floor litter could become compacted and untidy with the associated offensive odor and fly control problems, thus presenting additional management problems.

Results herein reported substantiate in part the findings of DíazMedina and Randel (3) obtained with unbalanced rations of unknown formulation. They tend to disprove the theory of excess or toxic effects of some minerals present (6). These data indicate that the only limitation of the present dry slops' by-product does not appear to be that of excess minerals, a situation that may be solved in the near future once an economically feasible demineralization process is developed, nor of only compensating for caloric deficiency, which was done in this study with some practical success in diets containing up to $15 \%$ dry slops, when feed utilization was compared. A more careful evaluation of other possible causes, such as the biological value of the protein fraction present in these diets, that could have been lowered by the process used in drying the slops (9), may explain the decreased re- 
sponses in production obtained in this study as the level of dry slops was increased.

The overall data indicate that in practical laying diets, any incorporation-substitution with the presently produced dry slops should not exceed a level higher than $15 \%$.

\section{RESUMEN}

Dietas balanceadas (isonitrogenadas e isocalóricas) que contenían entre 0 y $35 \%$ de mosto deshidrato se compararon, usando gallinas Liornas Blancas de la línea Kimber, alojadas en jaulas individuales de alambre. El estudio duró 12 semanas a partir del momento en que la manada de pollonas llegó a $50 \%$ de producción. Se usó un diseño de bloques incompletos parcialmente balanceado, con 6 gallinas alimentadas individualmente por tratamiento. La producción, peso del huevo, eficiencia de utilización del alimento, espesor del cascarón y calidad interna del huevo fueron los criterios comparativos.

Cuando se comparó la producción y utilización del alimento de los diferentes grupos, se observó una declinación relativamente escalonada no estadísticamente significativa, desde 5 hasta $20 \%$ de mosto. Aparentemente, más de $15 \%$ no se justifica desde el punto de vista práctico; más $20 \%$ de mosto resultó marcadamente inferior.

Los pesos medios del huevo y la gallina, la calidad interna media del huevo y el espesor medio del cascarón no fueron afectados por niveles tan altos de mosto deshidratado como $35 \%$.

Los altos niveles de potasio, magnesio y sulfato presentes en las dietas experimentales no afectaron el metabolismo del calcio asociado con la formación del cascarón.

En los grupos que recibieron dietas con un contenido mayor de $15 \%$ de mosto deshidratado, los huevos producidos se mancharon permanentemente y las aves también se ensuciaron marcadamente.

\section{LITERATURE CITED}

1. Association of Official Agricultural Chemists, Official Methods of Analysis, 12th ed, Wash., D.C., 1975.

2. Bearse, G. E., McClary, C. F., and Miller, V. L., "Vacuatone" in chick starting rations, West Wash. Agric. Exp. Stn. Rep. for year ending March 1940, (From Chem. Abs. 36: 5280, 1942).

3. Díaz-Medina, M., and Randel, P. F., Dried rum distillery stillage in laying rations, J. Agric. Univ. P.R. (In press).

4. Greweling, T., An extractive procedure for the determination of total calcium, magnesium, and potassium in plant tissue, J. Agric. Food Chem. 10: 138, 1962.

5. Morell de González, I., and Molini, A. E., Disposal of rum distillery wastes, Environmental Protection Agency, Project WPD-226-01, Progress Rep., 1971.

6. National Research Council, Nutrient requirements of poultry, 6th ed, Nat. Acad. Sci., Wash., D.C., 1971.

7. - Joint United States-Canadian Tables of Feed Compusition, 'ub. 1684, Nat. Acad. Sci., Wash., D.C., 1969.

8. Pérez-Escolar, R., The soil conditioning properties of blackstrap molasses and rum distillery slops, Ph.D. Thesis, Rutgers University, New Brunswick, N. J., 1962.

9. Saavedra, D., Molini, A., and García, H., Dehydration of rum distillery slops, Rum Pilot Plant, Agric. Exp. Stn., Univ. P.R., Mayagüez Campus, Prog. Rep., 1977.

10. Scott, M. L., Nesheim, M. C., and Young, R. J., Nutrition of the Chicken, M. L. Scott \& Associates, Ithaca, N.Y., 1969. 